\title{
An Empirical Study on Impacts of Brand Image of Travel Agencies on Customer Purchase Intentions
}

\author{
Meixian $\mathrm{He}^{1, \text { a }}$, Zhenquan Sha ${ }^{2, \mathrm{~b}}$ and Yuanyuan Yang ${ }^{3, \mathrm{c}}$ \\ ${ }^{1,2,3}$ School of Business Administration, South China University of Technology \\ Guangzhou, 510640, P.R. China \\ amx-he101@126.com, bbmzhqsha@scut.edu.cn, ${ }^{\mathrm{c}} 462696540 @ q q . c o m$
}

Keywords: brand image; purchase intention; travel agencies

\begin{abstract}
Travel agencies, as an important carrier for the development of tourism, their inadequacies in brand building have limited further development of tourism. In this paper, the impact of travel agencies' brand image on customer purchase intention was empirically examined from the perspective of consumer awareness. The results show that travel agencies' service images, brand personality as well as organization image have positive effects on consumer purchase intention significantly, while for consumers' individual characteristics, only disposable income acts similarly.
\end{abstract}

\section{Introduction}

Chinese travel industry has been developing rapidly because of increasing of disposable income and changing consumption concept. As the symbolic enterprise of travel industry, travel agencies play an important role in the whole tourism industry chain. According to Report on Brand Image of Beijing Travel Agencies (2010), however, unsatisfactory service quality and weak awareness of brand image construction restrict Chinese travel agencies from further development. Experience attribute of tourism products makes customers fail to experience its quality and service level before consumption, leading tourism brand an immeasurable effect in information delivery of tourism product. Meanwhile, brand image is an asset, and a good tourism brand image can be a core competition via customer loyalty, product premium and capital operation of successful brand. Moreover, in process of establishing brand image, only the brand identified by customers can possibly impress customers and stimulate their purchase intention. Therefore, it is critical to explore factors impact on purchase intention for travel agencies' continuing growth.

However, more than half of relevant researches focus on normative research method currently, while empirical research method only accounts for one eighth $(\mathrm{Li}, 2012)^{[1]}$. Furthermore, the research perspective is limited to travel enterprises for their own brand building. To make research results more guiding-practical, based on a theoretical analysis, an empirical study was employed to examine different impacts of four dimensions of brand image on customer purchase intention from perspective of tourism customers' cognition to travel agencies' brand image.

\section{Literature Review and Hypotheses}

Brand Image. Brand is an intangible asset that enterprise provides unique value and commitments to customers via establishing different identification. It is such a complicated and comprehensive symbol of brand attribute, name, package, reputation and advertising style, including perception, value, image as well as quality. Brand image is an overall perception of customers on a brand, resulting from customers' inferring from information relevant to the brand. Therefore, a clear brand image enable customers to identify and evaluate products or services, reduce purchasing cognitive risk, confirm what needs are met and enjoy differentiation and satisfaction. According to Oliver (1981), brand image was first proposed by David Ogilvy from perspective of brand position in 1950's ${ }^{[2]}$. Since then it keeps on changing and promoting with development of market, economy and people's further understandings of image ${ }^{[3-5]}$. Kapferer (1992) ${ }^{[3]}$ proposed Brand Identity Prism, including six facets of physical facet, personality, cultures, relationship, reflected consumer and 
consumer mentatlisation, which are interrelated as a whole. In addition, a comprehensive brand identity planning model with a four-fold perspective has been developed by David A. Aaker (1996) ${ }^{[4]}$ Based on the four distinct perspectives, he suggested managers to consider a brand as a product, an organization, a person and a symbol. This model seems to be stronger and better to reflect the construction of brand identity system. Besides, Fan and Chen (2002) ${ }^{[5]}$ developed another comprehensive measurement model for brand image based on Aaker's brand identity model.

Travel agencies belong to special service enterprise brands, so it is more objective to evaluate market performance of travel agencies based on their brand image from customers' experience and feelings. According to Aaker's (1996) brand identity planning model as well as Professor Fan's comprehensive evaluation model of brand image, this study regards brand image of travel agencies as four dimensions, namely organization brand image, service brand image, person brand image and symbol brand image. Besides, evaluation indicators for each dimension are redesigning without interfering from the same tourism products designed by different tourism organizations.

Purchase Intention. For constitution of consumers purchase intention, popular perspectives are from customers' attitude, perception value and perception risks. Both Kim and Littrell use famous Fishbein model to evaluate attitude of tourists. The results show that tourists' attitude to the tourism culture influence their purchase intention of souvenirs. Zhou et al. (2004) propose that consumers' attitude to food safety affect their acceptance of food thus purchase intention. According to Sondergaard (2005) ${ }^{[6]}$, consumers' attitude to enzyme product is a top-down structure process: firstly customers have to form a general attitude to the product; then conduct an overall evaluation to technology; consequently a specific evaluation of risks and benefits; finally produce purchase intention. This indicates that attitude plays a key and the-first-impressive role in the formation of customer purchase intention. Approval attitude helps customers to come up with positive purchase intention. This paper tries to explore factors impact on purchase intention from perspective of consumers' attitude, and purchase attitude results from purchase desire. Thus according to Sondergaard (2005), purchase intention is constituted both by purchase attitude and purchase desire.

Related Studies. The empirical study in Singapore indicates that the main factors influencing consumers to choose travel agencies are perceived value and travel agencies' reputation(Hui \&Wan, $2005)^{[7]}$, and it is easier for female consumers to combine purchase intention with travel agencies image compared to male. In addition, age and income level are significant to affect consumers' decision. Based on 493 samples, Heung and Zhu (2005) reveal that safety is the most important factor for consumers to choose travel agencies, and then is travel agencies' reputation. Six influencing factors were extracted, namely, interoperability, customer satisfaction, evaluation of travel facilities, quality of service, travel agencies image and brand character of service, impacting differently on demographic variables of gender, marital status, age, occupation and family income ${ }^{[8]}$.

Brand researches on travel agencies are increasing with broader perspectives in China recently. But most of scholars proposed methods and approaches to shape travel agencies brand based on current situation of domestic travel agencies (Chen, 2007), or discussed construction of travel agencies brand from perspective of enterprise ethics (Guo \& Hu, 2007). Diao (2008) explored the problems to shape travel agencies' brand based on integrated marketing, and Chen (2008) investigated relationship between tourism motivation and tourism consumption behavior for young consumers after 80s. However, these studies focus on normative method to conduct descriptive research and it is requested to consider accuracy. And the research perspective is limited for travel agencies to evaluate its own brand shaping. Therefore this paper explores image shaping of travel agencies based on different purchase intention resulting from tourism consumers' cognition to brand image of travel agencies.

Hypotheses. Owing to highly complicated purchase decision making process, we ignore influence factors including context factor and dynamic variation, and only regard consumers' individual characteristics variables as intermediary variable in this study, so as to clear the impact of brand image on consumer purchase intention. Based on above reviews, the hypotheses are proposed as follows:

H1: Service image has a significant impact on consumer purchase intention. 
H2: Organization image has a significant influence on consumer purchase intention.

H3: Brand personality has a significant influence on consumer purchase intention.

H4: Brand symbol image has a significant influence on consumer purchase intention.

H5: Consumer individual characteristics significantly affect the impact of brand image on consumer purchase intention.

Besides, eight sub-hypotheses are also proposed. Respectively, H1a, H2a, H3a and H4a represents travel agency service image, organization image, brand personality, symbol image have positive and significant effects on consumer purchase attitude. And $\mathrm{H} 1 \mathrm{~b}, \mathrm{H} 2 \mathrm{~b}, \mathrm{H} 3 \mathrm{~b}$ and $\mathrm{H} 4 \mathrm{~b}$ represents travel agency service image, organization image, brand personality and symbol image have positive and significant effects on consumer purchase desire.

\section{Methodology}

SPSS12.0 is employed for exploratory factors as well as reliability analysis, variance analysis and regression analysis. The questionnaire is designed and pre-tested by 30 students with different majors, rating on 5-point Likert scale. The scales are adopted from the related studies with reasonable adjustment. There are 31 items for scales and 6 questions for personal information, including brand image (A1-A8 for organization image, B1-B5 for service image, C1-C5 for brand personality, and D1-D5 for symbol image), purchase intention (E1-E8) and consumers' individual status (F1-F6).

The questionnaire was electronically delivered via E-mail. A random sample of 200 responders produced a response of 168 questionnaires with a response rate of $84 \%$, and 156 valid questionnaires with a valid response rate of $78 \%$. The descriptive statics result showed that 86 respondents were male $(55.13 \%)$, while the rest 70 were female $(44.8 \%)$. With regard to age distribution, $54.5 \%$ of respondents are under 25 -year-old and $27.5 \%$ are 26 to 29 years old. At the age of 30 to 35 , it occupied $9.6 \%$ and 36 to 40 is $5.8 \%$ and over 40 years old is $2.5 \%$. For monthly income, there were $37.18 \%$ of respondents receiving below RMB 3000yuan a month, $41.67 \%$ of respondents were between RMB $3000-5000 y u a n$, and about $13.46 \%$ received RMB 5000-8000yuan, 5.13\% got monthly pay of RMB $8000-10000 y u a n$, while there are roughly $2.56 \%$ of respondents receiving over $10000 y u a n$ monthly.

\section{Data Analysis and Results}

Exploratory Factor and Validity Analysis. Cronbach's $\alpha$ for organization image and symbol image (0.727), service image (0.791), brand personality (0.725) indicates good measurement reliability, and authoritative measure model and indicators are adopted to ensure content validity. According to principal component analysis, Eigen value of 1 act as standard cutting point for data and variance maximization of orthogonal rotation is adopted. $\mathrm{KMO}=0.850$ with a significant test of sphericity of Bartlett $(\mathrm{P}<0000)$ shows it is suitable for factor analysis. The result of factor analysis shows that there are 5 factors with accumulated explain variance as $64.512 \%$, indicating high validity of the questionnaire. At the first factor analysis, the fifth factor only contains two items including A4 and $\mathrm{C} 1$ thus being cut off. At the second factor analysis, there are four factors with Eigen value greater than $1,9.175,2.341,1.526$ and 1.254 respectively, accounting for explained variability of $38.93 \%, 11.45 \%, 7.27 \%$ and $5.97 \%$ respectively, totally contributing $53.32 \%$ to the variation. The first factor contains A1, A2, A3, A8, B1, B2, B3, B4, B5, C2 and C5, focusing on service ability, which is called as 'service ability factor'. The second factor includes D1, D2, D3, D4 and D5 called 'symbol image factor'. The third factor containing C3 (safety and reliability) and C4 (felling elegant) are called 'brand personality factor', the last one with A5 (high quality service organization) and A7 (Social responsibility) are 'organization image factor'. These are consistent with the predicting model.

Variance Analysis. This study considers age, monthly income, gender, travel frequency and choose frequency of travel agencies as control variables. The results of single factor analysis of variance are shown in Table 1. Except for income factor with a significant influence $(\mathrm{P}=0.000<0.05)$, 
the other factors have not significant influence on the process of consumer choosing travel agencies. Thus H5 is accepted, indicating customers' personal income significantly affects purchase intention.

Table 1: Results of Variance Analysis

\begin{tabular}{|l|c|c|c|c|c|}
\hline $\begin{array}{l}\text { Personal } \\
\text { feature of travel } \\
\text { consumer }\end{array}$ & $\begin{array}{l}\text { Frequency } \\
\text { of travel } \\
\text { agencies } \\
\text { choose }\end{array}$ & $\begin{array}{l}\text { Different } \\
\text { travel times }\end{array}$ & $\begin{array}{l}\text { Different } \\
\text { income }\end{array}$ & $\begin{array}{l}\text { Different } \\
\text { age }\end{array}$ & Gender \\
\hline F Value & 0.246 & 1.678 & 6.408 & 0.79 & 1.702 \\
\hline $\begin{array}{l}\text { Significance } \\
\text { probability }\end{array}$ & 0.782 & 0.175 & 0 & 0.534 & 0.139 \\
\hline
\end{tabular}

Correlation and Regression Analysis. The correlation analysis result (Table 2) shows that four dimension factors of brand image for travel agencies are highly correlated to purchase attitude, purchase desire and purchase intention.

Table 2: Results of Correlation analysis

\begin{tabular}{|l|l|l|l|}
\hline & Purchase Attitude & Purchase Desire & Purchase Intention \\
\hline Organization image & $401^{* *}$ & $431^{* *}$ & $480^{* *}$ \\
\hline Service image & $482^{* *}$ & $482^{* *}$ & $669 * *$ \\
\hline Brand personality & $502 * *$ & $602^{* *}$ & $632^{* *}$ \\
\hline Symbol image & $371 * *$ & $496^{* *}$ & $492^{* *}$ \\
\hline
\end{tabular}

$* *$ : high correlation at the level of $\mathrm{a}=0.01$

To further explore the above relationship, four independent variables are put into regression equation via regression process. In detail, purchase attitude, purchase desire and purchase intention are treated as dependent variables, while organization image $(\beta 1)$, service image $(\beta 2)$, brand personality $(\beta 3)$ and symbol image $(\beta 4)$ as independent variables, so as to get three regression equations. The significance of each regression correlation as shown in Table3:

Table3: Regression Equation Coefficient

\begin{tabular}{|l|l|l|l|l|l|l|l|l|l|l|}
\hline & \multicolumn{2}{|l|}{$\begin{array}{l}\text { Equation of regarding purchase } \\
\text { attitude as dependent variable }\end{array}$} & \multicolumn{2}{|l}{$\begin{array}{l}\text { Equation of regarding purchase } \\
\text { desire as dependent variable }\end{array}$} & \multicolumn{2}{|l}{$\begin{array}{l}\text { Equation of regarding purchase } \\
\text { intention as dependent variable }\end{array}$} \\
\cline { 2 - 11 } & $\begin{array}{l}\text { Coefficient } \\
\text { Value }\end{array}$ & $\begin{array}{l}\mathrm{T} \\
\text { Value }\end{array}$ & Significance & $\begin{array}{l}\text { Coefficient } \\
\text { Value }\end{array}$ & $\begin{array}{l}\mathrm{T} \\
\text { Value }\end{array}$ & Significance & \multicolumn{2}{l}{$\begin{array}{l}\text { Coefficient } \\
\text { Value }\end{array}$} & $\begin{array}{l}\text { T } \\
\text { Value }\end{array}$ & Significance \\
\hline Constant & 0.486 & 1.051 & .295 & 0.496 & 1.718 & 0.088 & 0.491 & 1.699 & 0.092 \\
\hline $\begin{array}{l}\text { Organization } \\
\text { image }(\beta 1)\end{array}$ & 0.225 & 1.481 & .141 & 0.079 & 2.647 & 0.043 & 0.152 & 2.596 & 0.012 \\
\hline $\begin{array}{l}\text { Service image } \\
(\beta 2)\end{array}$ & 0.351 & 3.196 & .002 & 0.497 & 7.203 & 0.000 & 0.424 & 6.133 & 0.000 \\
\hline $\begin{array}{l}\text { Brand } \\
\text { personality } \\
(\beta 3)\end{array}$ & 0.373 & 1.988 & .049 & 0.196 & 2.970 & 0.037 & 0.284 & 2.425 & 0.017 \\
\hline $\begin{array}{l}\text { Symbol image } \\
\beta 4)\end{array}$ & 0.033 & .241 & .810 & 0.098 & 0.830 & 0.408 & 0.032 & 0.377 & 0.706 \\
\hline
\end{tabular}

The results show that service image with a greater coefficient in three regression equations is highly significant, also brand personality and organization image with greater coefficients are significant. However, significance of symbol image fails to pass examination in the equations, the same as organization image in the equation of regarding purchase attitude as dependent variable. Constant coefficients for three regression equations fail to pass examination as well. The regression equations are made as follows:

Regarding purchase attitude as dependent variable:

$Y 1=0.351 \beta 2+0.373 \beta 3$.

Regarding purchase desire as dependent variable: 
$Y 2=0.079 \beta 1+0.497 \beta 2+0.196 \beta 3$.

Regarding purchase intention as dependent variable:

$Y=0.152 \beta 1+0.424 \beta 2+0.284 \beta 3$.

These analyses reveal that service capability and quality of travel agencies are the most concerned for consumers to purchase travel products. And whether personalized service provided can meet their different needs is the second consideration, followed by organization image. Organizational symbol image has no significant direct impact on consumers' purchase intention. To conclude, H1, H2, H3, $\mathrm{H} 2 \mathrm{a}, \mathrm{H} 3 \mathrm{a}, \mathrm{H} 1 \mathrm{~b}, \mathrm{H} 2 \mathrm{~b}$ and $\mathrm{H} 3 \mathrm{~b}$ are strongly accepted, while $\mathrm{H} 1 \mathrm{a}, \mathrm{H} 4, \mathrm{H} 4 \mathrm{a}$ and $\mathrm{H} 4 \mathrm{~b}$ are rejected. For $\mathrm{H} 5$, only income factor of consumers' personality characteristics significantly affect purchase intention.

\section{Conclusion}

Basically these results accord with current situation of domestic travel agencies and consumption habits of tourists. Service image is the most concerned, and brand personality and organization image also contribute to customers' purchase intention. Although symbol image shows no significant effect on purchase intention, which is not consistent with what we expected, their strong correlation suggests symbol image building should not be ignored. With regard to non-significant influence for organization image on purchase attitude, customers may more concern about service content instead of external factors like organization image when they choose travel agencies. As a whole, creating travel agencies brand is a comprehensive and systematic process involving different areas. In practice, shaping service image and visual image, enhancing service quality management and improving the overall image are critical for travel agencies to improve customers' future purchase intention.

On the other hand, limitation of investigation scope and sample size exists, and research methods need to be further improved. Though correlation analysis and regression analysis are efficient to explore impact of each factor of travel agencies image on purchase intention, other methods may help to make stronger evidences. Finally, as for the preliminary research on travel agencies' brand image, this paper only considers its effects on consumers' purchase intention. Service convenience or factors influencing on consumers' selection have not yet considered and can be studied later.

\section{References}

[1] Li Xiaofang. Research and literature review on China Travel Agency product [J]. Journal of Suzhou University.2012, 27(6):30-34.

[2] Oliver, R.L. Measurement and Evaluation of Satisfaction Processes in Retail Settings [J]. Journal of Retailing,1981(1): 25-48.

[3] Kapferer, Jean -Noel, Strategic Brand Management, The Free Press, 1992.

[4] Aaker, David A., Building Strong Brand s, The Free Press, 1996.

[5] Fang and Chen. A comprehensive evaluation model of brand image and its application [J].Nankai Journal (Philosophy and Social Sciences),2002(03).

[6] Sondergaard et.al. Consumer attitudes to enzymes in food production. Trends in Food Science \& Technology. 2005(16): 466-474.

[7] Hui TakKee, Wan, D. Factors affecting consumers' choice of a travel agency: the case of Singapore [J]. Journal of Travel \& Tourism Marketing, 2005, (19)(4): 1-12.

[8] Heung, V.C.S. \& Phoenix Zhu. Factors Affecting Choice of a Travel Agency for Domestic Tourism: The Case of Shanghai Residents in China [J] Journal of Travel \& Tourism Marketing, 2005,19(4). 13-25. 